\title{
Testing Hungarian oak (Quercus frainetto Ten.) provenances in Romania
}

\author{
Ecaterina Nicoleta Apostol, \\ Elena Stuparu, \\ Virgil Scărlătescu, \\ Marius Budeanu
}

\section{Introduction}

Hungarian oak (Quercus frainetto Ten.) is a tree species native to the Mediterranean and southeastern Europe (Albania, Bosnia and Herzegovina, Bulgaria, Croatia, Czech Republic, Greece, Italy, Macedonia, Romania, Serbia, Slovakia) and Asian Turkey. It has been formerly introduced in Slovenia and, despite the name, its native/non-native status in Hungary is still uncertain (Király 2007, IUCN 2017). Previous research on the genetic diversity of oak species indi-

$\square$ National Institute for Research and Development in Forestry "Marin Dracea”, Voluntari, 128 Eroilor Boulevard, 077190, Ilfov County (Romania)

@ Marius Budeanu

(budeanumarius@yahoo.com)

Received: Mar 25, 2019 - Accepted: Oct 23, 2019

Citation: Apostol EN, Stuparu E, Scarlatescu V, Budeanu M (2020). Testing Hungarian oak (Quercus frainetto Ten.) provenances in Romania. iForest 13: 9-15. - doi: 10.3832/ifor3108-012 [online 2020-01-08]

Communicated by: Marco Borghetti

In this study ten Hungarian oak provenances from Southern Romania were tested in two comparative trials 10 years after planting. The diameter at breast height (dbh) and tree height (Th) were measured in family progenies and the survival rate was determined. In both trials, the local provenances (Bals and Seaca 2) revealed superior fitness in terms of growth and adaptability traits, confirming the recommendation of using local provenances with priority in afforestation activities. Based on the measured traits, families which ranked in the first ten positions at age 3 and age 10 years were identified in both trials. The analysis of variance revealed statistically significant differences in growth traits between provenances and families in both comparative trials. Duncan's test for $5 \%$ transgression probability revealed different results for dbh and Th in terms of provenance homogeneity in the two test sites, with a superior homogeneity in the Aramadia trial for dbh and in the Bals trial for Th. Growth performances of the Hungarian oak provenances were significantly influenced by the experimental location and by the interactions between provenance, family and locality, suggesting that maximum precaution must be taken in the choice of forest reproductive materials to be planted in different environmental conditions. The family mean heritability $\left(h_{f}^{2}\right)$ was significantly lower than the individual heritability $\left(h^{2}{ }_{i}\right)$, suggesting the possible adoption of an individual selection strategy in the next stage of the current breeding programme. The juvenile-adult correlations will be made at the age of 40 years and will take advantage of the results of this study to shorten the testing period for the selection of genetically improved material in Hungarian oak.

Keywords: Age-to-age Correlations, Breeding, Forest Steppe, Oaks' Adaptability, Selection Strategy

cated that Q. frainetto belongs to the genus section Dascia, which is genetically close to Q. pubescens and clearly differentiated from Q. robur and Q. petraea (Finkeldey 2001, Petit et al. 2002, Belletti et al. 2005, Curtu et al. 2007, Fortini et al. 2015).

The importance of Hungarian oak mainly comes from its ability to grow on highly compact soils in low productivity areas (Kitikidou et al. 2015) and by its capacity of resprouting after fire (Milios et al. 2017). It is a meso-xerophilous species which grows well in the plain and forest-steppe areas (Curtu et al. 2011, Milios et al. 2014, Batziou et al. 2016). In some countries of the southeastern Europe (e.g., Greece, Bulgaria), Hungarian oak is the dominant deciduous oak species in terms of wood production (Papachristou et al. 2005, Bergmeier \& Dimopoulos 2008, Lyubenova et al. 2009, Mauri et al. 2016, Milios et al. 2016, 2017). Hungarian oak forests are listed under the EU Habitats Directive (code 9280 - Bergmeier et al. 2010). Also, it is listed as a vulnerable species in Slovakia (Feráková et al. 2001), while in Greece it is considered as the least tolerant to drought among oak species (Fotelli et al. 2000). In the United Kingdom, outside of its natural range, Q. frainetto showed the highest radial growth up to 10 years of age but the highest sensitivity to drought out of 5 oaks species at age of 45 years (Sanders et al. 2014). In Bul- garia, during the seasonal drought period (August), its physiological activity is reduced, particularly in the oldest stands (Velichkova Wolkerstorfer et al. 2011).

The Hungarian oak in Romania reaches the northern limit of its natural range (Fig. 1). Its current distribution in Romania comprises approximately 130,000 ha (which represents $2 \%$ of the total forest area), growing especially in the forest steppe of Oltenia and Muntenia regions. Here, the most extensive Hungarian oak forests of the whole natural range are found on the Cotmeana platform, where it can reach up to $80 \%$ of share in term of species composition (Seaca forest - Sofletea \& Curtu 2007). Increasing the adaptability of the species by genetic improvement could greatly increase the ecological, economic and social values of Hungarian oak stands (Cetera et al. 2018) as well as enhance the conservation of this species in its natural habitat. Genetic improvement programmes include the individual selection of plus-trees from the most valuable populations (including forest genetic resources and seed sources catalogues) and testing their progeny in multisite comparative trials (Wright 1976). In general, Hungarian oak stands regenerate naturally in Romania, although there are many situations where gap filling, re-establishments or substitutions are required, in which forest reproductive materials orig- 

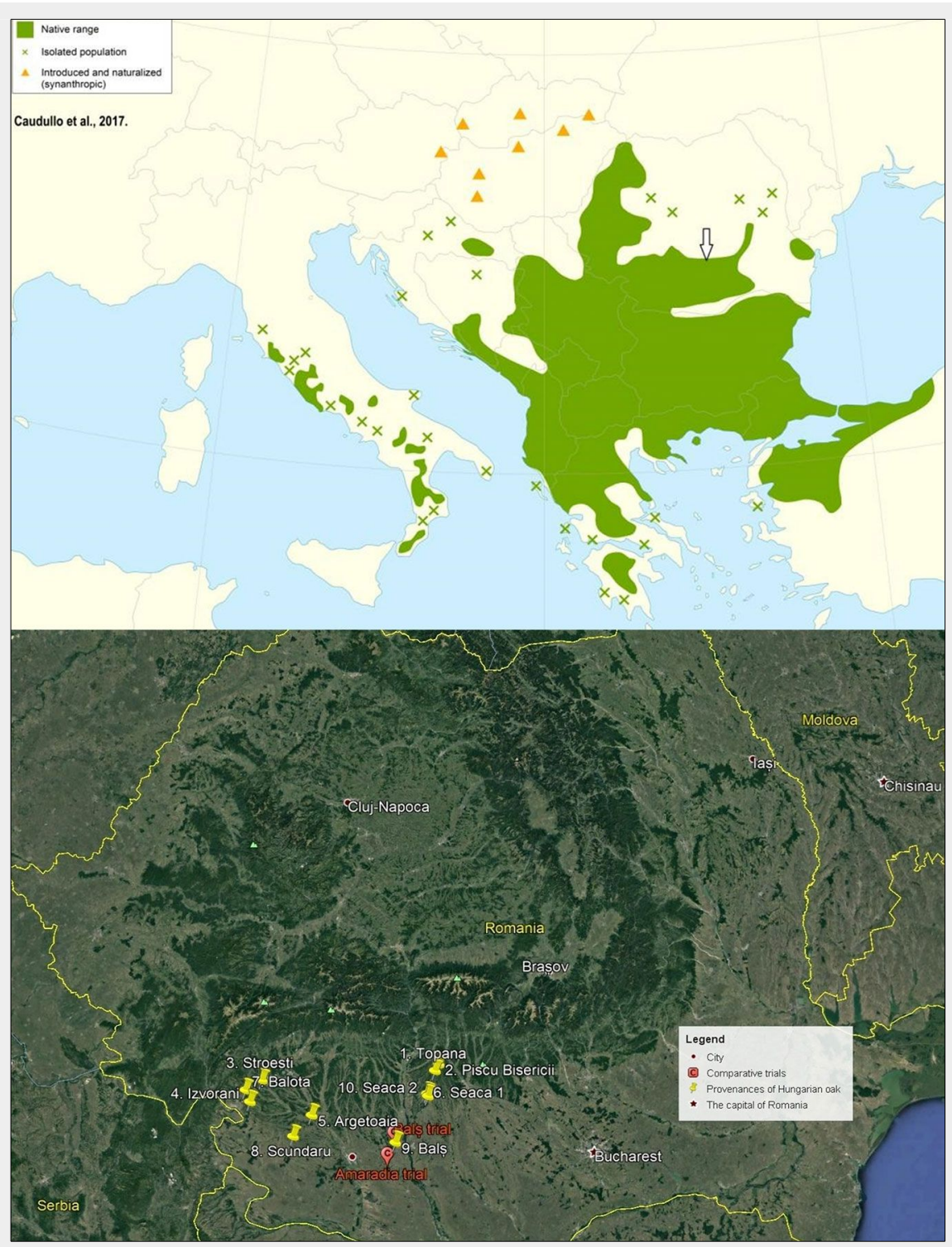

Fig. 1 - (top): Natural range of Hungarian oak (Quercus frainetto Ten.) in southeastern Europe (source: Caudullo et al. 2017); (bottom): locations of comparative trials (red pins) and sites of origin of the tested populations (yellow pins) in Romania.

inating from selected seed sources are needed (Blujdea 2000). One of the most important challenges for Romanian forest geneticists is to identify, preserve, test and promote those tree species with high adaptability to the forest-steppe area of Southern Romania, and the Hungarian oak is undoubtedly one of these.

It has been reported that the adaptability of forest tree populations to climate change is, to some extent, determined by individual inbreeding levels (Lloret \& García 2016). This study aims to analyse 10 Hun garian oak provenances from southern Romania, which have been tested in two com parative trials established in the same region. The main objectives were: (i) to identify the provenances showing the highest degree of adaptation and the best-performing families within them; (ii) to analyse the growth performances of local provenances; (iii) to determine the influence of the testing site and the interaction be- tween locality, provenance, and family; (iv) to analyse the age-to-age correlations at the provenance and family levels as well as the correlations between traits and the ecological gradients of the site of origin of populations; $(v)$ to determine the variance components and the narrow-sense heritability.

The obtained results will be used for determining the future juvenile-adult correlations in the current breeding programme.

\section{Materials and methods}

In this study, the term population will be used henceforth with the meaning of provenances' origin.

Ten populations of Hungarian oak (Quercus frainetto Ten.) were selected across the natural distribution range of the species in Southern Romania (Fig. 1): two in the Oltenia plain ( $\mathrm{J} 2$ provenance region) and eight in the Subcarpathian region of the Outer Southern Carpathians ( $\mathrm{C} 2$ region - Parnuta et al. 2012). A preliminary field analysis was carried out aimed at the selection and description of populations known as seed sources and their most representative (plus-) trees, taking into account several relevant phenotypic traits (dbh, total height, pruning height, crown diameter).

The selected populations (i.e., sites of origin) had an elevation range from 220 to $420 \mathrm{~m}$ a.s.l., with average annual rainfall between 515 and $630 \mathrm{~mm}$ and annual average temperatures between 10.2 and $11.7^{\circ} \mathrm{C}$. All selected sites were characterized by predominantly pure Hungarian oak stands or mixed with $10 \%$ Turkey oak (Quercus cerris L.). The stand age was between 85 and 145 years.

To determine the genetic variation within the natural populations under different environmental conditions, two comparative trials were established with seedlings from seed harvested from the plus-trees of all 10 populations, taking advantage of the abundant fructification occurred in the autumn of 2003.

The experiment was carried out in two comparative trials with the following locations and environmental characteristics: (i) Bals trial $\left(44^{\circ} 24^{\prime} \mathrm{N}, 24^{\circ} 12^{\prime} \mathrm{E}\right.$; altitude $320 \mathrm{~m}$ a.s.l.), Olt county, managed by the Bals forest district and located in V Bistrita production unit (plot 97E, area $0.81 \mathrm{ha}$ ) in an oak stand of medium productivity on luvosoil; (ii) Amaradia trial $\left(44^{\circ} 15^{\prime} \mathrm{N}, 24^{\circ} 08^{\prime} \mathrm{E}\right.$; altitude $260 \mathrm{~m}$ a.s.l. - Fig. 2), Dolj county, managed by the Amaradia forest district and located in IV Viisoara production unit (plot $95 \mathrm{~A}$, area $1.0 \mathrm{ha}$ ) in a mixed oak stand (sessile oak, Turkey oak and Hungarian oak) of medium productivity on luvosoil.

In both trials, the annual average temperature is $10.5^{\circ} \mathrm{C}$, with $-2.8^{\circ} \mathrm{C}$ in January (coldest month) and $20.8{ }^{\circ} \mathrm{C}$ in July (warmest month). Annual precipitation is $540 \mathrm{~mm}$, $64 \%$ of that being registered in the bioactive vegetation season, from March to September (Parnuta et al. 2011)

The study material consisted of 10 Hungarian oak provenances, each composed of six families (maternal trees), tested in the two comparative trials described above. The experimental design is a split-plot type, with 10 populations and 6 families per population, established with 3 replications in the Bals trial and 4 replications in the Amaradia trial. In each unitary plot, the families were represented by 12 seedlings, planted with a scheme of $1.5 \times 2 \mathrm{~m}$ (Fig. 2).

For the analysis of adaptive and growth performances, the following variables were measured: (i) survival rate (Sr, \%) for each family; (ii) diameter at breast height $(\mathrm{dbh}, \mathrm{mm}$ ) and root collar diameter (Drc, $\mathrm{mm}$ ), measured using an electronic calliper; (iii) total height (Th, $\mathrm{m}$ ) measured at ages three and ten using a Vertex $\mathrm{IV}^{\circledast}$ instrument (Hanglöf $A B$, Långsele, Sweden).

The data obtained for all traits were processed using the software STATISTICA ${ }^{\oplus}$ ver. 10.0 (StatSoft Inc., Tulsa, OK, USA). The Kolmogorov-Smirnov test was applied to 
Fig. 2 - The Amaradia comparative trials on Hungarian oaks provenances at age of 10 years (left) and the experimental design

(right).
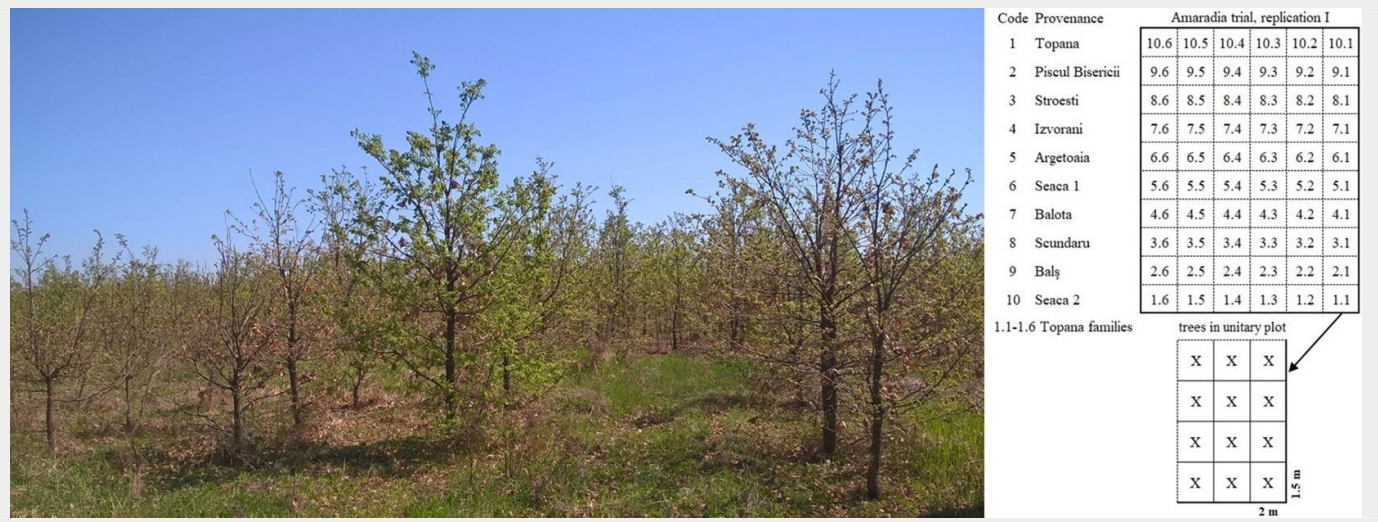

check the normal distribution of variables, and the assumptions of analysis of variance (ANOVA) were verified using Levene's test. The total variance was split into the variance due to replications, provenances, families and the variance of error (residual) by applying the ANOVA test, corresponding to the adopted experimental design (Nanson 2004, White et al. 2007) and the biological material type. The significance level of the differences was established using the Fisher's $(F)$ test for the transgression probabilities of $5 \%, 1 \%$ and $0.1 \%$. The ranking of populations and their separation into homogeneous groups was achieved using the Duncan test for a $5 \%$ transgression possibility. The statistical analysis was based on individual tree measurements using the mathematical model developed by Nanson (2004 - eqn. 1)

$$
Y_{i j k}=\mu+\alpha_{i}+\beta_{j}+\varepsilon_{i j k}
$$

where $Y_{\mathrm{ijk}}$ is the performance of the $k^{\text {th }}$ individual trees in the $j^{\text {th }}$ family in the $i^{\text {th }}$ replications, $\mu$ is the overall mean, $\alpha_{i}$ is the effect of the $i^{\text {th }}$ replication, $\beta_{\mathrm{j}}$ is the effect of the $j^{\text {th }}$ family, and $\varepsilon_{\mathrm{ijk}}$ is the random error associated with the $i j k^{\text {th }}$ trees. This model allows for the analysis of the mean effect of the three factors. For the determination of the variance components needed to calculate the heritability a different statistical model was used, which also include the interaction among factors (Nanson 2004).

Provenances $\times$ localities interaction were investigated using factorial ANOVA, in which the total variance was calculated for locality, provenance, family and theirs interactions (Nanson 2004).

The narrow-sense individual heritability $\left(h^{2}\right)$ and half-sib family mean heritability $\left(\mathrm{h}_{\mathrm{f}}{ }^{\mathrm{f}}\right)$ were calculated as follows (Nanson 2004):

$$
\begin{aligned}
& h_{i}^{2}=\frac{\sigma_{A}^{2}}{\sigma_{P h 2}^{2}}=\frac{4 \sigma_{f}^{2}}{\left(\sigma_{f}^{2}+\sigma_{f \times r}^{2}+\sigma_{e}^{2} / r\right)} \\
& h_{f}^{2}=\frac{\sigma_{f}^{2}}{\sigma_{P h 1}^{2}}=\frac{\sigma_{f}^{2}}{\left(\sigma_{f}^{2}+\sigma_{e}^{2} / r\right)} \\
& \sigma_{f}^{2}=\sigma_{A}^{2} / 4
\end{aligned}
$$

where $\sigma_{\text {Ph1 }}^{2}$ and $\sigma_{\text {Ph2 }}^{2}$ are the phenotypic variances, $\sigma_{A}^{2}$ is the additive genetic variance, $\sigma_{f}^{2}$ is the family variance, $\sigma_{f \times r}^{2}$ is the family $\times$ replication interaction variance, $\sigma_{\mathrm{e}}^{2}$ is the variance within plot and $r$ is the number of replications. In experiment with halfsib families $\sigma_{A}^{2}=4 \sigma_{f}^{2}$ (Mihai \& Mirancea 2016).

The genetic correlations were calculated as the ratio of the traits covariance and the square root of their additive genetic variances (Falconer \& Mackay 1996). Pearson's correlations between the analysed traits and the ecological gradients of the provenances origin were also determined. Both type of correlations were calculated based on family means.

\section{Results}

\section{Survival rate (Sr)}

In assessing the genetic variability between provenances, the survival rate is an important indicator of adaptability for populations of different geographic origins when facing to new environmental conditions.

In the Amaradia trial, the survival rate had values ranging from $45.8 \%$ for the Scundaru population to $69.1 \%$ for the Balota population, with an average of $62.1 \%$ (Fig. 3). Among the families with the highest survival rate, families 1 and 2 from Piscul Bisericii reached $85 \%$ of survival, similar to family 5 from Balota. Of all the families tested in the Amaradia trial, at 10 years after plantation, $81 \%$ had survival rates over $50 \%$.

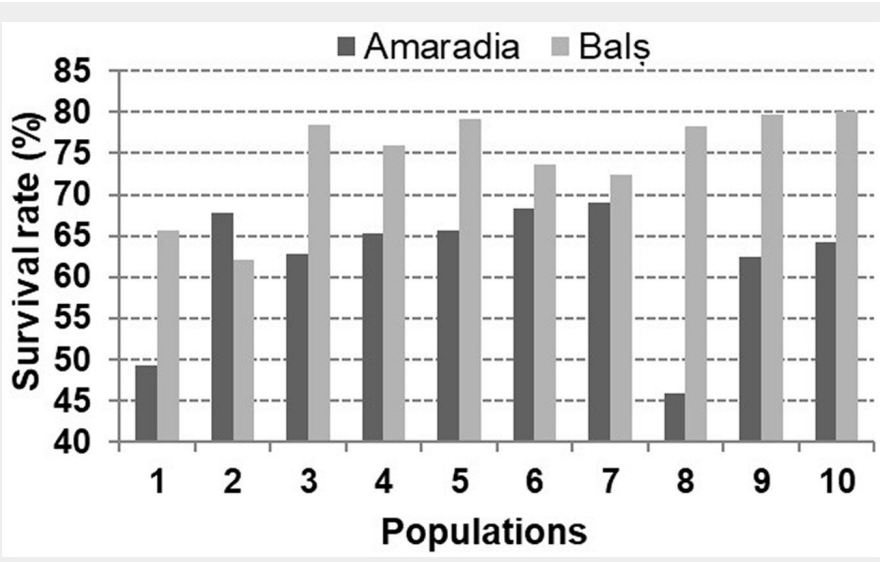

In the Bals trial, the survival rate had values ranging from $62 \%$ for the Piscul Bisericii population to $80 \%$ for Seaca 2 population, with an average of $74 \%$ (Fig. 3). The family with the highest survival rate (97\%) belongs to the Izvorani population, followed by families from Seaca 2 ( 5 out of the 6 tested families had survival rate over $79 \%$ ).

Analyses of the intrapopulational variability in the Amaradia trial showed variation coefficients ranging from 20\% (Izvorani population) to $54 \%$ (Scundaru), while in the Bals trial values ranged between 19\% (Bals) and $40 \%$ (Topana population). The homogeneity was higher in the Bals trial for $70 \%$ of the tested families, the local provenance (Bals) being the most homogeneous.

\section{Diameter at breast height ( $d b h$ )}

In the Amaradia trial, the average dbh value was $40.9 \mathrm{~mm}$, with values between $37.0 \mathrm{~mm}$ (Balota) and $44.4 \mathrm{~mm}$ (Izvorani Tab. 1). At age 10, $1.8 \%$ of the measured trees had values above the mean by two standard deviations ( $\mathrm{dbh}>79.3 \mathrm{~mm}$ ). The highest average family value $(52.8 \mathrm{~mm})$ was found for family 6 of the Seaca 2 population, and the families 2, 3 and 5 from Izvorani had mean dbh values between 49.8 and $51.6 \mathrm{~mm}$. The analysis of variance revealed a significant influence $(p<0.05)$ of provenance and an insignificant influence of family on dbh (Tab. 2).

In the Bals comparative trial, the average $\mathrm{dbh}$ value was $20.8 \mathrm{~mm}$, ranging from 18.8 $\mathrm{mm}$ (Argetoaia population) and $24.6 \mathrm{~mm}$ (Bals population - Tab. 1). Out of the 1110
Fig. 3 - Survival rate of the Hungarian oak provenances at age of 10 years in the two comparative trials (Amaradia and Bals). The population code is the same as in Fig. 1. 
Tab. 1 - Results of the Duncan test for diameter at breast height (dbh) in the Amaradia and Bals trials. (Hom $5 \%$ ): homogeneous groups for $5 \%$ transgression probability.

\begin{tabular}{|c|c|c|c|c|c|c|c|c|}
\hline \multirow{3}{*}{$\begin{array}{l}\text { Provenance } \\
\text { Izvorani }\end{array}$} & \multicolumn{3}{|c|}{ Amaradia trial } & \multirow{3}{*}{$\begin{array}{l}\text { Provenance } \\
\text { Bals }\end{array}$} & \multicolumn{4}{|c|}{ Bals trial } \\
\hline & \multirow{2}{*}{$\begin{array}{c}\begin{array}{c}\mathrm{dbh} \\
(\mathrm{mm})\end{array} \\
44.4 \\
\end{array}$} & \multicolumn{2}{|c|}{ Hom $_{5 \%}$} & & \multirow{2}{*}{$\begin{array}{c}\begin{array}{c}\mathrm{dbh} \\
(\mathrm{mm})\end{array} \\
24.6\end{array}$} & \multicolumn{3}{|c|}{ Hom $_{5 \%}$} \\
\hline & & $* * *$ & - & & & $* * *$ & - & - \\
\hline Seaca 2 & 44.2 & $* * *$ & - & Seaca 2 & 22.7 & $* * *$ & $* * *$ & - \\
\hline Piscul Bisericii & 41.4 & $* * *$ & $* * *$ & Scundaru & 22.7 & $* * *$ & $* * *$ & - \\
\hline Bals & 41.2 & $* * *$ & $* * *$ & Stroiesti & 20.8 & - & $* * *$ & $* * *$ \\
\hline Argetoaia & 41.2 & $* * *$ & $* * *$ & Seaca 1 & 20.1 & - & $* * *$ & $* * *$ \\
\hline Stroiesti & 40.9 & $* * *$ & $* * *$ & Topana & 20.0 & - & $* * *$ & $* * *$ \\
\hline Scundaru & 39.4 & $* * *$ & $* * *$ & Piscul Bisericii & 19.9 & - & $* * *$ & $* * *$ \\
\hline Seaca 1 & 39.4 & $* * *$ & $* * *$ & Izvorani & 19.6 & - & $* * *$ & $* * *$ \\
\hline Topana & 38.0 & - & $* * *$ & Balota & 19.3 & - & - & $* * *$ \\
\hline Balota & 37.0 & - & $* * *$ & Argetoaia & 18.8 & - & - & $* * *$ \\
\hline
\end{tabular}

Tab. 2 - Results of the ANOVA for dbh and total height in the Amaradia and Bals trials. (SS): sum of squares; (DF): degrees of freedom; (MS): mean square; (F): Fisher's test; $(*): p<0.05 ;(* *): p<0.01 ;(* * *): p<0.001$.

\begin{tabular}{llrrrrrrrr}
\hline \multirow{2}{*}{ Variable } & Source of & \multicolumn{9}{c}{ Amaradia trial } & \multicolumn{7}{c}{ Bals trial } \\
\cline { 2 - 10 } & variation & SS & DF & MS & F & SS & DF & MS & F \\
\hline dbh & Replication & 61 & 3 & 20 & 0.055 & 4662.2 & 2 & 2331.1 & $24.3^{* * *}$ \\
& Provenance & 7732 & 9 & 859 & $2.349^{*}$ & 3660.7 & 9 & 406.7 & $4.24^{* * *}$ \\
& Family & 761 & 5 & 152 & 0.416 & 2922.8 & 5 & 584.6 & $6.093^{* * *}$ \\
& Error & 520124 & 1422 & 366 & - & 104855.0 & 1093 & 95.9 & - \\
\multirow{2}{*}{$\begin{array}{l}\text { Total } \\
\text { height }\end{array}$} & Replication & 8.43 & 3 & 2.81 & $4.49^{* *}$ & 10.64 & 2 & 5.319 & $27.0^{* * *}$ \\
& Provenance & 18.30 & 9 & 2.03 & $3.25^{*}$ & 7.54 & 9 & 0.838 & $4.25^{* * *}$ \\
& Family & 0.18 & 5 & 0.04 & 0.06 & 4.11 & 5 & 0.821 & $4.17^{* * *}$ \\
& Error & 890.28 & 1422 & 0.63 & - & 215.37 & 1093 & 0.197 & - \\
\hline
\end{tabular}

trees in the trial, 46 (4.1\%) showed dbh values exceeding the overall mean by more than two standard deviations (SD = 10.2). The highest $\mathrm{dbh}$ mean values were found for families 1, 2 and 6 belonging to the Bals population and for families 2 and 3 from Seaca 2. All the factors considered showed a highly significant effect $(p<0.001)$ on dbh after ANOVA (Tab. 2).

The Duncan test for the transgression probability of $5 \%$ showed a superior homogeneity in the Amaradia trial, separating the tested populations in two homoge-

neous groups including 8 and 2 provenances, respectively. In the Bals trial, three groups were detected, with the first one composed by only three provenances (Tab. 1).

Significant differences in mean dbh between trials are likely due the fact that in Bals cut-backs were performed after seedling establishment to prevent dieback caused by frequent droughts in that area.

Total height (Th)

In the Amaradia trial, the average value of

Tab. 3 - Results of the Duncan test for tree height in the Amaradia and Bals trials. (Hom ${ }_{5 \%}$ ): Homogeneous groups for $5 \%$ transgression probability.

\begin{tabular}{|c|c|c|c|c|c|c|c|c|c|}
\hline \multirow{3}{*}{$\begin{array}{l}\text { Provenance } \\
\text { Izvorani }\end{array}$} & \multicolumn{5}{|c|}{ Amaradia trial } & \multirow{3}{*}{$\begin{array}{l}\text { Provenance } \\
\text { Bals }\end{array}$} & \multicolumn{3}{|c|}{ Bals trial } \\
\hline & \multirow{2}{*}{$\begin{array}{c}\text { Height }(\mathrm{m}) \\
3.27\end{array}$} & \multicolumn{4}{|c|}{ Hom $_{5 \%}$} & & \multirow{2}{*}{$\begin{array}{c}\text { Height }(\mathrm{m}) \\
2.18\end{array}$} & \multicolumn{2}{|c|}{ Hom $_{5 \%}$} \\
\hline & & $* * *$ & - & - & - & & & $* * *$ & - \\
\hline Seaca 2 & 3.21 & $* * *$ & $* * *$ & - & - & Seaca 2 & 2.14 & $* * *$ & - \\
\hline Argetoaia & 3.11 & $* * *$ & $* * *$ & $* * *$ & - & Scundaru & 2.13 & $* * *$ & - \\
\hline Stroiesti & 3.07 & $* * *$ & $* * *$ & $* * *$ & $* * *$ & Stroiesti & 2.10 & $* * *$ & $* * *$ \\
\hline Bals & 3.04 & - & $* * *$ & $* * *$ & $* * *$ & Balota & 1.99 & - & $* * *$ \\
\hline Scundaru & 3.00 & - & - & $* * *$ & $* * *$ & Izvorani & 1.99 & - & $* * *$ \\
\hline Piscul Bisericii & 3.00 & - & - & $* * *$ & $* * *$ & Argetoaia & 1.98 & - & $* * *$ \\
\hline Seaca 1 & 2.99 & - & - & $* * *$ & $* * *$ & Piscul Bisericii & 1.98 & - & $* * *$ \\
\hline Balota & 2.96 & - & - & $* * *$ & $* * *$ & Seaca 1 & 1.97 & - & $* * *$ \\
\hline Topana & 2.89 & - & - & - & $* * *$ & Topana & 1.97 & - & $* * *$ \\
\hline
\end{tabular}

Th was $3.06 \mathrm{~m}$, ranging from $2.89 \mathrm{~m}$ for the Topana population to $3.27 \mathrm{~m}$ for the Izvorani population (Tab. 3). Out of the total number of tested trees, $1.5 \%$ exceed the average height value plus two standard deviations $(\mathrm{SD}=0.8)$ showing $\mathrm{Th}>4.66 \mathrm{~m}$. The highest values were recorded for the progeny from Seaca 2 and Argetoaia populations. Analysis of performances of each family revealed that family 2 from the Izvorani population had the highest Th $(3.66$ $\mathrm{m}$ ), while the smallest mean Th value was recorded by the fourth family of the Scundaru population $(2.36 \mathrm{~m})$. ANOVA revealed a highly significant influence $(p<0.001)$ of provenance and a significant influence $(p<$ 0.01) of the replication on Th (Tab. 2).

In the Bals trial, the average value of Th was $2.06 \mathrm{~m}$, with a range between $1.97 \mathrm{~m}$ in Topana and Seaca 1 and $2.18 \mathrm{~m}$ in the Bals population (Tab. 3). The analysis of family performances revealed that family 2 from Bals and family 3 from Seaca 2 population had the highest average Th $(2.43 \mathrm{~m}$ and $2.36 \mathrm{~m}$, respectively). The smallest Th values in this trial was for family 4 from the Piscul Bisericii population, with an average of $1.63 \mathrm{~m}$. All the factors considered showed a significant effect $(p<0.001)$ on Th after ANOVA (Tab. 2).

The Duncan test for the transgression probability of $5 \%$ showed a superior homogeneity in the Bals trial, separating the tested populations in two homogeneous groups including 4 and 6 provenances, respectively (Tab. 3). Contrastingly, four groups were detected in the Amaradia trial, the first being composed of four provenances.

\section{Provenance and family ranking at 3 and} 10 years

The analysis of the growth performance of trees (dbh and height) at ages 3 and 10 years allowed to track the evolution of the ranking of families and provenances in the comparative trials. In the Aramadia trial, Izvorani and Seaca 2 populations ranked first at both 3 and 10 years of age, while Balota was the last one (Tab. 4). Moreover, six out of the best 10 ranking families at age 3 were also present in the top ranking at the age of 10 years, and three of them were from the Izvorani provenance, which had the best performance for both growth traits at the age of 10 years.

In the Bals trial, the local provenance (Bals) registered the highest values for $\mathrm{dbh}$ and Th at both ages (Tab. 4). In addition, the Seaca 2 and Scundaru provenances remained at the top of ranking since age 3 to age 10. Conversely, the Argetoaia and Topana populations were at the bottom of the rank order for $\mathrm{dbh}$ and Th, respectively (Tab. 4). At the family level, out of the best 10 ranking families at age of 3 years, four for $\mathrm{dbh}$ and six for Th were also in the top 10 at the age of 10 years. For dbh, the bestperforming families were from Bals and Seaca 2 (two from each), while for Th, besides the two provenances mentioned 
above (Bals with two families), Scundaru, Stroesti and Topana were in the top ten at both ages.

\section{Correlations}

In the Amaradia and Bals comparative trials, the age-to-age correlations were, in general, significant for both growth traits (Tab. 5), the $r$ value ranging between 0.26 and 0.60 .

In both trials, more intensive genetic correlations were found between Th and $\mathrm{dbh}$ at the same age (Tab. 5), compared to ageto-age correlations. In Bals trial, at age 10 a significant and positive correlation was detected between $\mathrm{Th}$ and $\mathrm{Sr}$, while $\mathrm{dbh}$ and $\mathrm{Sr}$ value were also positively correlated, though not significantly. Moreover, a significant correlation of the latitude and altitude of the site of origin (provenance) with $\mathrm{dbh}$ and Th at age 10 was detected, while in Amaradia such correlation was not significant at age 10 (Tab. 5). This finding seems to contradict the expectations, as the Amaradia trial is located further south and at lower altitude than the Bals trial.

\section{Genotype $\times$ environment interaction}

For both the analysed traits, a highly significant effect of locality (experimental site) was detected $(p<0.001)$. Also, the differences between provenances were highly significant (Tab. 6), while differences between families of the same provenance were not significant. Furthermore, the locality $\times$ provenances and locality $\times$ provenances $\times$ families interactions were statistically significant, indicating that provenances did react differently to the change of the environmental conditions (Tab. 6).

\section{Heritability}

The narrow-sense individual heritability showed a high genetic control for the growth traits analysed, especially for $\mathrm{dbh}$ (Tab. 7). In the Amaradia trial, $h^{2}{ }_{i}$ was 0.39 for $\mathrm{dbh}$ and 0.28 for Th, while in Bals the highest heritability for $\mathrm{dbh}(0.46)$ and the lowest for Th (0.1) were recorded. The family mean heritability $\left(h_{f}^{2}\right)$ at age of 10 years was much lower, varying between 0.05 and 0.21 , the best result being registered in Bals trial for dbh (Tab. 7).

\section{Discussion}

Ten years after plantation, ANOVA revealed significant differences between and within provenances of Hungarian oak for selected growth traits (Tab. 2). In the Amaradia comparative trial, the provenance factor contributed to the total variation by $61 \%$ for $\mathrm{dbh}$ and $37 \%$ for Th, while in the Bals trial, the provenance contribution was only $12 \%$ for both traits. The family factor had a smaller contribution (1-17\%), as well as the individual variability within trees (3-26\%). The replication factor had the major impact (except for dbh in the Amaradia trial), accounting for $51-74 \%$ of the total variance. This fact strengthens the need of establishing multiple replications in comparative tri-
Tab. 4 - Growth ranking evolution of the tested provenances.

\begin{tabular}{|c|c|c|c|c|c|c|}
\hline Trial & $\begin{array}{c}\text { dbh } \\
\text { ranking } \\
10 \text { years }\end{array}$ & Provenance & $\begin{array}{l}\text { Dcollar } \\
\text { ranking } \\
3 \text { years }\end{array}$ & $\begin{array}{c}\text { Th } \\
\text { ranking } \\
10 \text { years }\end{array}$ & Provenance & $\begin{array}{c}\text { Th } \\
\text { ranking } \\
3 \text { years }\end{array}$ \\
\hline \multirow{10}{*}{$\begin{array}{l}\frac{0}{7} \\
\frac{\pi}{0} \\
\frac{0}{0} \\
\frac{5}{\alpha}\end{array}$} & 1 & Izvorani & 3 & 1 & Izvorani & 3 \\
\hline & 2 & Seaca 2 & 1 & 2 & Seaca 2 & 2 \\
\hline & 3 & Piscul Bis. & 5 & 3 & Argetoaia & 6 \\
\hline & 4 & Bals & 2 & 4 & Stroesti & 7 \\
\hline & 5 & Argetoaia & 8 & 5 & Bals & 5 \\
\hline & 6 & Stroesti & 9 & 6 & Scundaru & 9 \\
\hline & 7 & Scundaru & 6 & 7 & Piscul Bis. & 1 \\
\hline & 8 & Seaca 1 & 7 & 8 & Seaca 1 & 4 \\
\hline & 9 & Topana & 4 & 9 & Balota & 8 \\
\hline & 10 & Balota & 10 & 10 & Topana & 10 \\
\hline \multirow{10}{*}{$\frac{\mathscr{n}}{\tilde{D}}$} & 1 & Bals & 2 & 1 & Bals & 5 \\
\hline & 2 & Seaca 2 & 1 & 2 & Seaca 2 & 1 \\
\hline & 3 & Scundaru & 3 & 3 & Scundaru & 3 \\
\hline & 4 & Stroesti & 4 & 4 & Stroesti & 6 \\
\hline & 5 & Seaca 1 & 7 & 5 & Balota & 10 \\
\hline & 6 & Topana & 8 & 6 & Izvorani & 4 \\
\hline & 7 & Piscul Bis. & 5 & 7 & Argetoaia & 8 \\
\hline & 8 & Izvorani & 6 & 8 & Piscul Bis. & 7 \\
\hline & 9 & Balota & 10 & 9 & Seaca 1 & 9 \\
\hline & 10 & Argetoaia & 9 & 10 & Topana & 2 \\
\hline
\end{tabular}

Tab. 5 - Age-to-age genetic correlations and the effect of the ecological gradients (phenotypic correlations) of the provenance origin in Amaradia (above diagonal) and Bals (below diagonal) trials. (Drc3y): root collar diameter at age three; (Th3y, Th10y): trees height at age three and ten; (Dbh10y): breast height diameter at age ten; (Lat $\mathrm{N}$ ): north latitude; (Lon E): east longitude; (Alt): altitude (a.s.I.); (MAT): mean annual temperature; (SAP): sum of the annual precipitation; $(*): p<0.05$.

\begin{tabular}{lllllllllll}
\hline Factors & Drc3y & Th3y & Dbh10y & Th10y & Sr10y & Lat N & Lon E & Alt & MAT & SAP \\
\hline Drc3y & - & $0.49^{*}$ & $0.40^{*}$ & $0.30^{*}$ & -0.04 & -0.10 & $0.26^{*}$ & 0.11 & -0.05 & -0.09 \\
\hline Th3y & $0.26^{*}$ & - & $0.45^{*}$ & $0.35^{*}$ & 0.16 & 0.03 & 0.18 & 0.19 & -0.04 & 0.02 \\
\hline Dbh10y & $0.38^{*}$ & $0.43^{*}$ & - & $0.59^{*}$ & 0.13 & -0.09 & 0.01 & 0.08 & 0.01 & 0.00 \\
\hline Th10y & $0.35^{*}$ & $0.44^{*}$ & $0.60^{*}$ & - & 0.14 & -0.09 & -0.13 & -0.01 & 0.13 & 0.08 \\
\hline Sr10y & 0.20 & 0.07 & 0.20 & $0.26^{*}$ & - & 0.04 & -0.04 & 0.03 & 0.10 & 0.21 \\
Lat N & -0.20 & -0.20 & $-0.29^{*}$ & $-0.30^{*}$ & $-0.40^{*}$ & - & - & - & - & - \\
\hline Lon E & 0.13 & 0.06 & 0.18 & 0.06 & -0.21 & - & - & - & - & - \\
\hline Alt & -0.07 & -0.16 & -0.23 & $-0.28^{*}$ & $-0.39^{*}$ & - & - & - & - & - \\
MAT & -0.12 & -0.18 & -0.09 & -0.05 & 0.11 & - & - & - & - & - \\
\hline SAP & $-0.28^{*}$ & $-0.34^{*}$ & $-0.35^{*}$ & $-0.32^{*}$ & -0.22 & - & - & - & - & - \\
\hline
\end{tabular}

Tab. 6 - Variance partition and genotype $\times$ environment interaction in Hungarian oak progeny trials. (DF): degrees of Freedom; (MS): mean square; (F): Fisher's test; $\left(^{*}\right)$ : p $<0.05 ;(* *): p<0.01 ;(* * *): p<0.001$.

\begin{tabular}{llrrc}
\hline Variable & Factors & DF & MS & \multicolumn{1}{c}{ F } \\
\hline DBH & Locality (L) & 1 & 225342 & $923^{* * *}$ \\
& Provenance (P) & 9 & 800 & $3.28^{* * *}$ \\
\cline { 2 - 5 } & Family (f) & 5 & 399 & 1.64 \\
& L $\times \mathrm{P}$ & 9 & 521 & $2.14^{*}$ \\
& $\mathrm{~L} \times \mathrm{F}$ & 5 & 501 & 2.05 \\
& $\mathrm{P} \times \mathrm{F}$ & 45 & 416 & $1.71^{* *}$ \\
& L $\times \mathrm{P} \times \mathrm{f}$ & 45 & 358 & $1.47^{*}$ \\
& Error & 2430 & 244 & - \\
Height & Locality (L) & 1 & 581 & $1371^{* * *}$ \\
& Provenance (P) & 9 & 1.44 & $3.40^{* * *}$ \\
& Family (f) & 5 & 0.55 & 1.29 \\
& L $\times \mathrm{P}$ & 9 & 1.1 & $2.61^{*}$ \\
& L $\times \mathrm{F}$ & 5 & 0.68 & 1.60 \\
\cline { 2 - 5 } & $\mathrm{P} \times \mathrm{F}$ & 45 & 1.08 & $2.54^{* * *}$ \\
& L $\times \mathrm{P} \times \mathrm{f}$ & 45 & 0.84 & $1.98^{* * *}$ \\
\cline { 2 - 5 } & Error & 2430 & 0.42 & - \\
\hline
\end{tabular}


Tab. 7 - Variance components, narrow-sense individual heritability $\left(h_{i}^{2}\right)$ and family mean heritability $\left(h_{f}^{2}\right)$ at age 10 years in Hungarian oak comparative trials.

\begin{tabular}{llccccccc}
\hline Trial & Trait & $\sigma_{\mathrm{f}}^{2}$ & $\sigma_{\mathrm{f} \times \mathrm{r}}^{2}$ & $\sigma_{\mathrm{e}}^{2}$ & $\sigma_{\mathrm{Ph} 1}^{2}$ & $\sigma_{\mathrm{Ph} 2}^{2}$ & $\boldsymbol{h}_{\mathrm{f}}^{2}$ & $\boldsymbol{h}_{\mathrm{i}}^{2}$ \\
\hline \multirow{2}{*}{ Amaradia } & $\mathrm{dbh}$ & 11.096 & 13.667 & 360 & 101.096 & 114.763 & 0.11 & 0.387 \\
\cline { 2 - 8 } & $\mathrm{Th}$ & 0.022 & 0.161 & 0.55 & 0.160 & 0.321 & 0.138 & 0.275 \\
\multirow{2}{*}{ Bals } & $\mathrm{dbh}$ & 7.32 & 29.36 & 82.1 & 34.68 & 64.04 & 0.211 & 0.458 \\
& $\mathrm{Th}$ & 0.003 & 0.065 & 0.17 & 0.060 & 0.125 & 0.05 & 0.096 \\
\hline
\end{tabular}

als to minimize the local microenvironmental variation at the experimental sites and its influence on provenance tests.

The Duncan test for $5 \%$ transgression probability presents different results for $\mathrm{dbh}$ and Th in terms of provenance homogeneity in the two testing sites. A superior homogeneity was observed in the Amaradia trial for $\mathrm{dbh}$, while for Th the homogeneity was superior in the Bals trial. For the advanced generation of the current breeding programmes, more variability is required (White et al. 2007).

The comparative analysis of the survival rate showed that at the current age (10 years), in both trials, a sufficient number of trees survived for all the populations and families. Indeed, the survival rate was more than $62 \%$ at the population level, with the exceptions of Topana and Scundaru provenances which had lower survival rates (49.3\% and $45.8 \%$, respectively) in the Amaradia trial. The best-performing population in both trials (Seaca 2) in terms of growth traits, also showed survival rates superior to the average by $3.4 \%$ and $8.1 \%$ in the Amaradia and Bals trials, respectively. In the Bals trial, the local provenance (Bals) had the second performances in terms of survival rate (after Seaca 2) and the first for growth traits. In addition, it showed the highest homogeneity among families in terms of survival rate.

The Bals and Seaca 2 populations can be considered as local provenances, as their site of origin is situated close to both trials, particularly the Bals provenance which is the closest (Fig. 1). Moreover, both populations were the best performing in terms of growth and adaptability in both trials. Such finding reinforces the recommendation for the priority use of local provenances in afforestation projects, also known as "the golden law of local provenances" (Sofletea 2005).

The age-to-age correlations were very significant for growth traits measured at 3 and 10 years in both trials. In addition, several populations and families were found at the top of the performance ranking at both ages. This type of correlation will be useful in the future to investigate the behaviour of provenances through time, providing support for genotype selection at the juvenile stage and thus reducing the length of breeding programmes (Rweyongeza 2016). However, the optimal age for selection has been intensely debated in the past and it is currently thought that it can be achieved from 20-30 years to an age equivalent to half the production cycle of the stand (Zobel \& Talbert 1984, Cotterill \& Dean 1988, De Sousa et al. 2005, White et al. 2007, Resende et al. 2012).

The provenances originated from high altitudes and from the northern part of the species range showed lower growth in the Bals trial, while we did not observe any influence of the site of origin on growth performances in the Amaradia trial. This contrasts with our expectations, as the Bals trial is located further to north and at an altitude higher than Amaradia.

The highly significant effect of genotype $x$ environment interaction suggests that maximum caution must be taken regarding the movement of forest reproductive materials across regions with different environmental conditions. The large and highly significant effect of the locality on growth performances of Hungarian oak provenances suggests the need of using the best performing provenances only in similar environmental conditions, preferably in the same region where the trials are performed.

The average values registered for family heritability $\left(h_{f}^{2}\right)$, which was significantly lower than the individual heritability $\left(h_{i}^{2}\right)$, denotes a high variability within families. This leads to the recommendation of adopting a strategy of individual selection for the next stage of the current breeding programme. However, in the case of the comparative trials analysed, the breeding strategy will be decided later (at 40 years), and will take advantage of the results of this study in order to shorten the testing period for genotype selection.

\section{Conclusions}

The best-performing provenances of Hungarian oak in Romania in term of growth traits were Izvorani and Seaca 2 at the Amaradia trial, while in the Bals trial the local provenance (Bals) is seconded by the Seaca 2 population, the latter being highlighted in both experiments. In both comparative trials, several families were identified which were among the ten best performing families both at 3 and 10 years.

ANOVA revealed significant differences between provenances and families for growth traits in both comparative trials. This genetic variation allows the breeder to choose those among the tested families which are best suited for the intended purpose. In the case of the analysed trials, the selection of the best-performing provenances will be made later, at the age of 40 years, when the juvenile-adult correlations (10 to 40 years) will be made based on the results of the present study.

Performances of the Hungarian oak provenances were highly significant influenced by trial site and the interactions between provenance, family and locality, which suggests maximum precaution when the movement of forest reproductive materials across regions with different climatic conditions is required. The family mean heritability $\left(h_{f}^{2}\right)$ was significantly lower than the individual heritability $\left(\mathrm{h}_{\mathrm{i}}{ }_{\mathrm{i}}\right)$, which recommend the adoption of individual selection strategy in the next generation of the current breeding programme.

To ensure a forest sustainable management in the context of climate change, with new pests and diseases, invasive alien species and wood products needs, breeding programmes should consider ex situ conservation as a critical strategy for the future. In addition, genetically improved forest tree species will be the main source of reproductive materials for future stable forests. Drought-resistant species (including Hungarian oak) will be highly appreciated in the future.

\section{Acknowledgments}

This paper was financed by the Romanian Ministry of Scientific Research and Innovation, in the frame of the RMSRI programme contracted with the National Institute for Research and Development in Forestry "Marin Dracea" (Project PN18040203 and PN19070 301).

\section{References}

Batziou M, Milios E, Kitikidou K (2016). Is diameter at the base of the root collar a key characteristic of seedling sprouts in a Quercus pubescens - Quercus frainetto grazed forest in north-eastern Greece? A morphological analysis. New Forests 48: 1-16. - doi: 10.1007/s11056016-9552-6

Belletti P, Leonardi S, Monteleone I, Piovani P (2005). Allozyme variation in different species of deciduous oaks from northwestern Italy. Silvae Genetica 54: 9-16. - doi: 10.1515/sg-2005-00 02

Bergmeier E, Dimopoulos P (2008). Identifying plant communities of thermophilous deciduous forest in Greece: species composition, distribution, ecology and syntaxonomy. Plant Biosystems 142: 228-254. - doi: 10.1080/1126350080215 0357

Bergmeier E, Petermann J, Schröder E (2010). Geobotanical survey of wood-pasture habitats in Europe: diversity, threats and conservation. Biodiversity Conservation 19: 2995-3014. - doi: 10.1007/s10531-010-9872-3

Blujdea V (2000). Cercetari ecofiziologice în cerete si grnitete afectate de fenomene de uscare [Ecophysiological research in the Turkey oak and Hungarian oak stands affected by drying phenomena]. PhD thesis, Forest Science Department, Transylvania University of Brasov, Brasov, Romania, pp. 43. [in Romanian]

Caudullo G, Welk E, San-Miguel-Ayanz J (2017). Chorological maps for the main European 
woody species. Data in Brief 12: 662-666. - doi: 10.1016/j.dib.2017.05.007

Cetera P, D’Auria M, Mecca M, Todaro L (2018). Gallic acid as main product in the water extractives of Quercus frainetto Ten. Natural Product Research 33 (19): 2864-2867. - doi: 10.1080/147 86419.2018.1503266

Cotterill PP, Dean CA (1988). Changes in genetic control of growth of radiata pine to 16 years and efficiencies of early selection. Silvae Genetica 37: 138-146.

Curtu AL, Gailing O, Leinemann L, Finkeldey R (2007). Genetic variation and differentiation within a natural community of five Oak species (Quercus spp.). Plant Biology 9: 116-126. - doi: 10.1055/s-2006-924542

Curtu AL, Moldovan IC, Enescu MC, Craciunesc I, Sofletea N (2011). Genetic differentiation between Quercus frainetto Ten. and Q. pubescens Willd. in Romania. Notulae Botanicae Horti Agrobotanici Cluj-Napoca 39: 275-282. - doi: $10.15835 /$ nbha3915633

De Sousa GP, Bortoletto N, Cardinal ABB, Gouvêa LRL, Da Costa RB, De Moraes MLT (2005). Age-age correlation for early selection of rubber tree genotypes in Sao Paulo State, Brazil. Genetics and Molecular Biology 28: 758-764. doi: 10.1590/S1415-47572005000500018

Falconer DS, Mackay TFC (1996). Introduction to quantitative genetics ( $4^{\text {th }}$ edn). Longman and Co., Harlow, NY, USA, pp. 360.

Feráková V, Maglocky Š, Marhold K (2001). Red list of fern and vascular plants. In: "Red list of plants and animals of Slovakia Nature conservation" (Marhold K, Baláž D, Urban P eds). Štátna Ochrana Prírody Publisher, Bystrica, Slovakia, pp. 44-76.

Finkeldey R (2001). Genetic variation of oaks (Quercus spp.) in Switzerland. 1. Allelic diversity and differentiation at isozyme gene loci. Forest Genetics 8: 185-195. [online] URL: http://kf. tuzvo.sk/sites/default/files/FG08-3_185-195.pdf Fortini P, Di Marzio P, Di Pietro R (2015). Differentiation and hybridization of Quercus frainetto, Q. petraea, and Q. pubescens (Fagaceae): insights from macro-morphological leaf traits and molecular data. Plant Systematics and Evolution 301: 375-385. - doi: 10.1007/s00606-0141080-2

Fotelli MN, Radoglou KM, Constantinidou H-IA (2000). Water stress responses of seedlings of four Mediterranean oak species. Tree Physiology 20: 1065-1075. - doi: 10.1093/treephys/20.16. 1065

IUCN (2017). Quercus frainetto. The IUCN red list of threatened species 2017 (Rivers MC, Khela S eds). Web site. - doi: 10.2305/IUCN.UK.2017

Király G (2007). Red list of the vascular flora of Hungary. Private edition, Sopron, Hungary, pp. 73.

Kitikidou K, Milios E, Tsirekis E, Pipinis E, Stampoulidis A (2015). Site quality assessment of de- graded Quercus frainetto stands in central Greece. iForest 8: 53-58. - doi: 10.3832/ifor1069007

Lloret F, García C (2016). Inbreeding and neighbouring vegetation drive drought-induced dieoff within juniper populations. Functional Ecology 30: 1696-1704. - doi: 10.1111/1365-2435.12655 Lyubenova M, Tzonev R, Pachedjieva K (2009). Floristic investigation of Quercus cerris and Quercus frainetto communities in Bulgaria. Biotechnology and Biotechnological Equipment 23 (suppl. 1): 314-317. - doi: 10.1080/13102818.2009.1 0818427

Mauri A, Enescu CM, Houston Durrant T, De Rigo $D$, Caudullo G (2016). Quercus frainetto in Europe: distribution, habitat, usage and threats. In: "European Atlas of Forest Tree Species" (San-Miguel-Ayanz J, De Rigo D, Caudullo G, Houston Durrant T, Mauri A eds). Publication Office of the European Union, Luxembourg, pp. 2, eo1de78. [online] URL: http://www.re searchgate.net/publication/299471053

Mihai G, Mirancea I (2016). Age trends in genetic parameters for growth and quality traits in Abies alba. iForest 9: 954-959. - doi: 10.3832/i for1766-009

Milios E, Kitikidou K, Andreadou P (2017). Sprouting characteristics of Quercus pubescens Willd. and Quercus frainetto Ten. trees after a wildfire: to cut or not to cut the burned trees? European Journal of Forest Research 136: 971-979. - doi: 10.1007/s10342-017-1085-9

Milios E, Kitikidou K, Dalakouras V, Pipinis E (2016). Diameter at breast height estimated from stumps in Quercus frainetto in the region of Evros in northeastern Greece. Cerne 22: 337344. - doi: 10.1590/01047760201622032193

Milios E, Pipinis E, Kitikidou K, Batziou M, Chatzakis S, Akritidou S (2014). Are sprouts the dominant form of regeneration in a lowland Quercus pubescens-Quercus frainetto remnant forest in Northeastern Greece? A regeneration analysis in the context of grazing. New Forests 45: 165177. - doi: 10.1007/s11056-013-9399-z

Nanson A (2004). Génétique et amélioration des arbres forestières [Genetic and forest trees breeding]. Les Presses Agronomiques, Gembloux, Belgium, pp. 712. [in French] [online] URL: http://books.google.com/books?id=i3Q3p tu1TDwC

Papachristou TG, Platis PD, Nastis AS (2005). Foraging behavior of cattle and goats in oak forest stands of varying coppicing age in Northern Greece. Small Ruminant Research 20: 181-189. doi: 10.1016/j.smallrumres.2005.05.006

Parnuta G, Stuparu E, Budeanu M, Scarlatescu V, Marica F-M, Lalu I, Filat $M$, Tudoroiu $M$, Lorent A, Daia M, Sofletea N, Curtu AL, Parnuta P, Nica M-S, Teodosiu M, Chesnoiu E-N, Marcu C (2011). Catalogul national al resurselor genetice forestiere [National catalogue of forest genetic resources]. Silvica Publishing House, Bucharest,
Romania, pp. 525. [in Romanian]

Parnuta G, Budeanu M, Stuparu E, Scarlatescu V, Chesnoiu E-N, Tudoroiu M, Filat $M$, Nica $M-S$, Teodosiu M, Lorent A, Daia M, Dinu C (2012). Catalogul national al materialelor de baza pentru producerea materialelor forestiere de reproducere [National catalogue of basic materials for the production of forest reproductive materials]. Silvica Publishing House, Bucharest, Romania, pp. 304. [in Romanian]

Petit R, Csaikl U, Bordács S, Burg K, Coart E, Cottrell J, Van Dam B, Deans D, Dumolin-Lapègue S, Fineschi S, Finkeldey R, Gillies A, Glaz I, Goicoechea PG, Jensen JS, König AO, Lowe AJ, Madsen SF, Mátyás G, Munro RC, Olalde M, Pemonge $\mathrm{M}-\mathrm{H}$, Popescu F, Slade D, Tabbener $\mathrm{H}$, Taurchini D, De Vries SGM, Ziegenhagen B, Kremer A (2002). Chloroplast DNA variation in European white oaks. Phylogeography and patterns of diversity based on data from over 2600 populations. Forest Ecology and Management 156: 5-26. - doi: 10.1016/S0378-1127(01)00645-4 Resende MFRJ, Munoz P, Acosta JJ, Peter GG, Davis JM, Grattapaglia D, Resende MDV, Kist M (2012). Accelerating the domestication of trees using genomic selection: accuracy of prediction models across ages and environments. New Phytologist 193: 617-624. - doi: 10.1111/j.1469-813 7.2011.03895.x

Rweyongeza DM (2016). A new approach to prediction of the age-age correlation for use in tree breeding. Annals of Forest Science 73: 1099-1111. - doi: 10.1007/s13595-016-0570-5

Sanders TGM, Pitman R, Broadmeadow MSJ (2014). Species-specific climate response of oaks (Quercus spp.) under identical environmental conditions. iForest 7: 61-69. - doi: 10.38 32/iforog11-007

Sofletea N (2005). Genetica si ameliorarea arborilor [Genetics and trees breeding]. "Pentru viata” Publishing House, Brasov, Romania, pp. 455. [in Romanian]

Sofletea N, Curtu AL (2007). Dendrologie [Dendrology]. Transylvania University Publishing House, Brasov, Romania, pp. 418. [in Romanian]

Velichkova Wolkerstorfer S, Wonisch A, Stankova T, Tsvetkova N, Tausz N (2011). Seasonal variations of gas exchange, photosynthetic pigments, and antioxidants in Turkey oak (Quercus cerris L.) and Hungarian oak (Quercus frainetto Ten.) of different age. Trees 25: 1043-1052. - doi: 10.1007/s00468-011-0579-1

White TW, Adams WT, Neale DB (2007). Forest genetics. $C A B I$ Publishing, Cambridge, UK, pp. 682.

Wright JW (1976). Introduction to forest genetics. Academic Press, New York, USA, pp. 463.

Zobel B, Talbert J (1984). Applied forest tree improvement. John Wiley and Sons, New York, USA, pp. 505. [online] URL: http://www.cab direct.org/cabdirect/abstract/19840699048 